\title{
Housing plans of the oldest: ageing in semi-rural areas in Sweden
}

\author{
Marianne Abramsson ${ }^{1}$ (D) . Jan-Erik Hagberg ${ }^{2}$
}

Received: 24 November 2017 / Accepted: 13 April 2019 / Published online: 19 April 2019

(c) The Author(s) 2019

\begin{abstract}
A number of smaller municipalities have decreasing population rates. Generally, the young move out, increasing the proportion of older people. To increase our understanding of the living conditions of an ageing population in small municipalities, a postal survey was conducted in three small, semi-rural municipalities in southern Sweden. In the survey the respondents answered questions about their living situation and their housing plans. The aim of this study was to investigate the housing situation and housing plans of the very old in semi-rural areas and research questions analysed for this study concerned the current housing situation and plans for future housing. A total of 1386 surveys were sent out in March 2014, to all inhabitants aged 80 years or more, residing in the ordinary housing market in the three municipalities, the response rate was $60 \%$. The results show that most of the respondents were firmly rooted in the area as most of them had lived in the municipality for more than 20 years and $60 \%$ had lived in their current dwelling for more than 20 years. Ageing in place was the dominating plan, although one quarter of the respondents answered that they did not know what would happen in the future. Those who planned to move wanted to move to housing that required less maintenance and to a more central location. Residential mobility is at play also in old age as $27 \%$ of the respondents had moved at some point during the last 10 years, i.e., after the age of 70 .
\end{abstract}

Keywords Older people $\cdot$ Survey data $\cdot$ Housing $\cdot$ Rural ageing $\cdot$ Semi-rural municipalities

\section{Introduction}

The depopulation of many Swedish rural areas has been going on for a long time and more evidently during certain periods in time (SCB 2015:80; SOU 2000:87). This is intimately connected to the expansion of urban areas. The young move to urban areas in pursuit of

Marianne Abramsson

marianne.abramsson@humangeo.su.se

Jan-Erik Hagberg

jan-erik.hagberg@liu.se

1 Department of Human Geography, Stockholm University, Stockholm, Sweden

2 Division Ageing and Social Change, Department of Social and Welfare Studies, Linköping University, Linköping, Sweden 
higher education and different opportunities, as do immigrants. But the cities grow also of their own accord, as birth rates are higher than in other areas in Sweden (SCB 2015:80). Due to the outmigration of the young from rural areas and increased life expectancy of the old, the population of these areas in particular is ageing. This changes the demographic structure, with the consequence that older people's needs become more important and a part of the political agenda when it comes to housing and care needs specifically.

Research on life in rural areas hitherto has been quite fragmentary. However, in international research on older people, issues concerning rural areas have received some attention (Burholt and Dobbs 2012; Keating 2008). For instance, the specific importance of older people's homes and neighbourhoods in rural areas has been investigated (Chapman and Peace 2008; Peace et al. 2006). For many years the political ambition has been, and still is, that older people should be able to age in place in ordinary housing (Fernandez-Carro and Evandrou 2014; Sandstedt and Abramsson 2012). This is most often in line with the preferences of older people themselves but with increasing age, a long-term dwelling may not be the optimal place to grow old (Hillcoat-Nallétamby and Ogg 2014). However, the possibilities to age in ordinary housing differ between different local housing markets as the supply of housing options suitable for an ageing population is especially small in rural housing markets (Paulsson 2008; Riksrevisionen 2014; Colsher and Wallace 1990). Despite the relatively large volume of housing research there is a lack of international as well as national knowledge about the housing situation and housing needs of older people in rural areas.

How to cater for the housing needs of older people in general is of concern and in rural areas in particular as municipalities that have suffered from depopulation have no or a very limited stock of new and accessible housing. These areas are defined as weak housing markets that have difficulties meeting the targets of the Swedish Housing Supply Act. This Act stipulates the responsibility of the municipality to ascertain that everyone in the municipality lives in good housing (SFS 2000; Riksrevisionen 2014). As there is a housing surplus in these municipalities, with housing companies experiencing financial problems it is difficult to find investors for new and modern housing that would better meet the needs of the households in those local housing markets. The municipalities themselves, are currently only commissioned to build housing for assisted living. The incentive for older people to leave a house in owner-occupation to move into a more easily maintained, but perhaps more costly, apartment is smaller as the accumulated wealth in housing in these areas can be limited. These issues were raised by the Swedish National Audit Office, in a report (Riksrevisionen 2014) in which they emphasised that the state has not provided the legal and financial means to municipalities with weak housing markets to make it possible for them to fulfil their responsibilities in regard to housing provision. The result is a lack of housing to cater for an ageing population in particular.

The aim of this paper was to investigate the housing situation and housing plans of the very old in semi-rural areas. This was done in order to increase our knowledge about the needs and demands of this group in that particular type of local housing market and to find out under which conditions the present housing situation is perceived as unsatisfactory or problematic. In the total population the proportion of the very old will increase in the future, in particular in rural areas. In these areas, older people can be assumed to be particularly vulnerable due to a demographic thinning process, because fewer people live in rural areas, and because service levels are particularly low while at the same time their needs and demands might not be different to those in more densely populated areas. A survey on living conditions was sent out to all individuals aged 80 years and above in three semi-rural municipalities in the south of Sweden. For this study, the results from the part of the survey linked to housing and housing conditions were analysed and presented. 


\section{A demographic shift with impact on the housing market}

In many countries across the world ageing of the population is taking place but this demographic shift is neither equally distributed across countries nor within countries. (SCB 2015:80). In addition, population growth and population loss are unequally distributed. The number of people 80 or older is expected to increase by $50 \%$ in 10 years, from just over 500,000 at the end of 2017 to just over 750,000 in 2028 (SCB 2018). The large cities are expected to increase in population by $37 \%$ in the next 40 years and the sparsely populated municipalities will decrease by $10 \%$ during the same time, affecting the dependency ratio. Geographical differences between areas can be seen as regards the proportion of older people. In some areas, that is, in small, rural municipalities in particular, the proportion of older people is higher than in growth areas. The major and large cities together with the suburban municipalities have the lowest proportions of older people. In Sweden a rapid transformation of the older population is taking place. Between 2005 and 2015, there was an increase in the number of young retirees in the 65-74 age group, between 2015 and 2025 a rapid increase of older retirees in the 75-84 age group will take place, followed by a near twofold increase in the number of the oldest old, people aged 85-94 between 2025 and 2035 (SCB 2015:80).

In the county of Östergötland in Sweden, where this study has been conducted, the proportion of inhabitants older than 65 will increase by $16 \%$, from about 92,500 in the year 2016 to about 107,000 individuals in the year 2030. The proportion of the population 85 years old and older is expected to increase by $40 \%$, from 12,606 to 17,654 individuals during the same period of time (Östsam 2012). This latter group is one of specific importance, as at this age housing and care needs drastically change due to declining health.

To understand the housing decisions made in old age we need to consider a number of questions. How do the increased life expectancy levels influence housing choices and preferences among older people when more years are spent in old age? What are the decisions made about the housing situation and what options are available to older people in rural areas? Is the housing situation at all considered, from the perspective of where the individual wants to spend the last years of life? If so, will relocation actually take place? Contrary to previous moves in life, residential mobility in very old age is irreversible as most moves take place as a result of declining health, to a smaller dwelling that entails a concurrent disbandment of the home (Ekerdt et al. 2004; Larsson Ranada and Hagberg 2014). To that extent a move in old age means looking back rather than forward, and from a residential mobility perspective can be considered a turning point.

It can be assumed that increased longevity and the fact that many people can expect to spend more years in retirement, will have an effect on the housing decisions made in old age and to a change in attitudes to housing as a "means to an end rather than an end in itself" as discussed by Clapham (2005, p. 213). Rubinstein and Parmelee discuss older people and their attachment to place (1992) and it is true that the majority of older people are stayers and do not move. However, an increase in the mobility rates has been seen in different studies (Angelini and Laferrère 2012; Tatsiramos 2006; Abramsson and Andersson 2015; Andersson and Abramsson 2012). In particular, relocation takes place in connection with old age and the loss of a partner, in particular as regard women, at which time moves are more likely to be made from owner occupation into a smaller dwelling in rented tenure (Abramsson et al. 2014; de Jong and Brouwer 2012; Bonnet et al. 2010; Tatsiramos 2006; Colsher and Wallace 1990; Litwak and Longino 1987). The latter is to a lesser extent available in rural areas where ownership is more prevalent (OECD 2007; SOU 2015:85). 
Housing policies that focus on ageing in place, that is, ageing in ordinary housing, even in very old age in combination with changing household structures, will, given the simultaneous growth in older population groups and in residential mobility rates, increase the need for suitable housing in the ordinary housing market, as this is where the vast majority will age.

\section{Tenure, gender and housing possibilities of older people in the Swedish housing market}

The vast majority, $96 \%$, of people over the age of 65 live in housing in the ordinary housing market in Sweden with just over $50 \%$ home owners and $20 \%$ in tenant cooperatives, the latter are dwellings bought and sold on the ordinary housing market but for which a monthly fee is also paid (SOU 2015:85). Men to a larger extent than women own their dwelling, of those 85 years old and older 40 percent of the men own their house compared to $20 \%$ of the women. Women on the other hand to a larger extent than men, live in tenant cooperative housing. Just over $20 \%$ live in municipal or private rented housing. The proportion of older people in rented housing increases with age (SOU 2015:85) indicating that older people make moves to smaller dwellings with limited responsibility for maintenance (Abramsson et al. 2014; Abramsson and Niedomysl 2008). Rented tenure in Sweden is secure as contracts are for an unlimited time and rents are negotiated within the corporate rent setting system in order to prevent sudden increases in rent levels (Andersson 2008; Andersson et al. 2007). This makes rented housing a viable housing choice which may not be the case in all countries (Elsinga and Hoekstra 2005).

In small municipalities that have suffered from many years of depopulation there is generally a lack of modern and accessible rented housing, as was emphasised by the Swedish National Audit Office (Riksrevisionen 2014). In these municipalities, ownership is by far the dominating housing type among older people and the supply of rented housing limited. The option of living together with your adult children is not at all common among older people in Sweden.

Ageing in place, that is to live and age in the ordinary housing market, has been the aim of Swedish housing policy towards older people and has been made possible with home and medical care to an increasing extent being provided in the homes. As a result, among the residents that live in assisted living facilities, that is housing that provide care $24 \mathrm{~h}$ a day and that is accessed based on need, the majority, 80\%, are older than 80 (Socialstyrelsen 2016). The number of places in this type of housing has decreased by $30 \%$ since the beginning of the 1990s despite an ageing population (Boverket 2013). Similarly, the average time lived after having been admitted in assisted living facilities has decreased, a result of the residents having much poorer health upon admission (Schön et al. 2016) and thus, spending more time in housing in the ordinary housing market. To cover the gap that has evolved between ordinary housing and assisted living facilities, housing alternatives specifically aimed at older people have developed in the ordinary housing market, such as senior housing for people from the age of 55 or 60 and extra care housing for those somewhat older, usually from the age of 70 . The latter has evolved with the help of a government grant.

Thus, a growing proportion of older and ageing people in combination with a reduction in the number of places in assisted living facilities has increased the need for housing in the ordinary housing market adequate for older people. The municipalities are responsible 
for housing provision as stipulated by the Housing Supply Act, that in short, states that the municipalities should plan for housing provision in order for all inhabitants to live in adequate housing (SFS 2000:1383). As the municipalities are not the actual provider of residential housing, except for assisted living facilities, the provision needs to be negotiated with housing providers according to regular business principles.

We have investigated the housing situation and housing plans of people in three semirural municipalities based on the results of a survey aimed at older individuals aged 80 years and older. The study and the results are presented below.

\section{Method and data}

The study is based on a postal survey containing 49 questions on what it is like to be old and to age in small municipalities and rural areas. It had the aim of increasing our knowledge about everyday life and ageing in such a geographical context. For this particular study we rely on the questions in the survey related to the housing situation and housing plans of the targeted group.

\subsection{Study area}

The study was conducted in three semi-rural municipalities in the south of Sweden, Valdemarsvik, Ydre and Åtvidaberg. We have defined them as semi-rural as they have in common that they are small municipalities, with a small municipal centre, have experienced depopulation continuously for many years, and the proportion of older people is increasing. Locations with substantial service levels and a varied labour market are within commuting distance-one can go back and forth in less than half a day, this distinguish them from the more remote Swedish municipalities in particular the inland, northern part of the country. Ydre is one of the smallest municipalities in Sweden, with a population of 3665 individuals and is the most rural of the three, traditionally based on industry as well as farming and forestry. Valdemarsvik is a coastal municipality that increases its population of 7634 rather substantially in summer. Its trade is based on fishing, farming, tourism and to some extent industry, and part of the municipality used to be known for its copper and brass industry. Connections to the city of Norrköping are frequent. Atvidaberg, the largest of the three, is an area previously dominated by the mining industry with a population of 11,440 individuals. It is also located closer to a large city, Linköping, to which many of its inhabitants commute. Since the start of this study, this municipality has experienced a slight increase in its population. Despite differences in population size, the actual geographical size of the municipalities is about the same (about $780 \mathrm{~km}^{2}$ ). Only Ydre had senior housing at the time of the study, extra care housing was not available in any of the municipalities (Figs. 1, 2).

\subsection{Survey design and analysis}

A survey containing 49 questions on different issues about ageing in rural areas and everyday life in old age was constructed. In addition to the questions on housing and housing plans that were used for the analysis presented in this paper questions relating to the use of a car, computer and mobile phone; engagement in associations; relations to neighbours; service provision (shopping, culture and care); the need for help and support and ageing in 
Fig. 1 Map showing where in Sweden the municipalities selected for the study are located (Map by Stefan Ene)
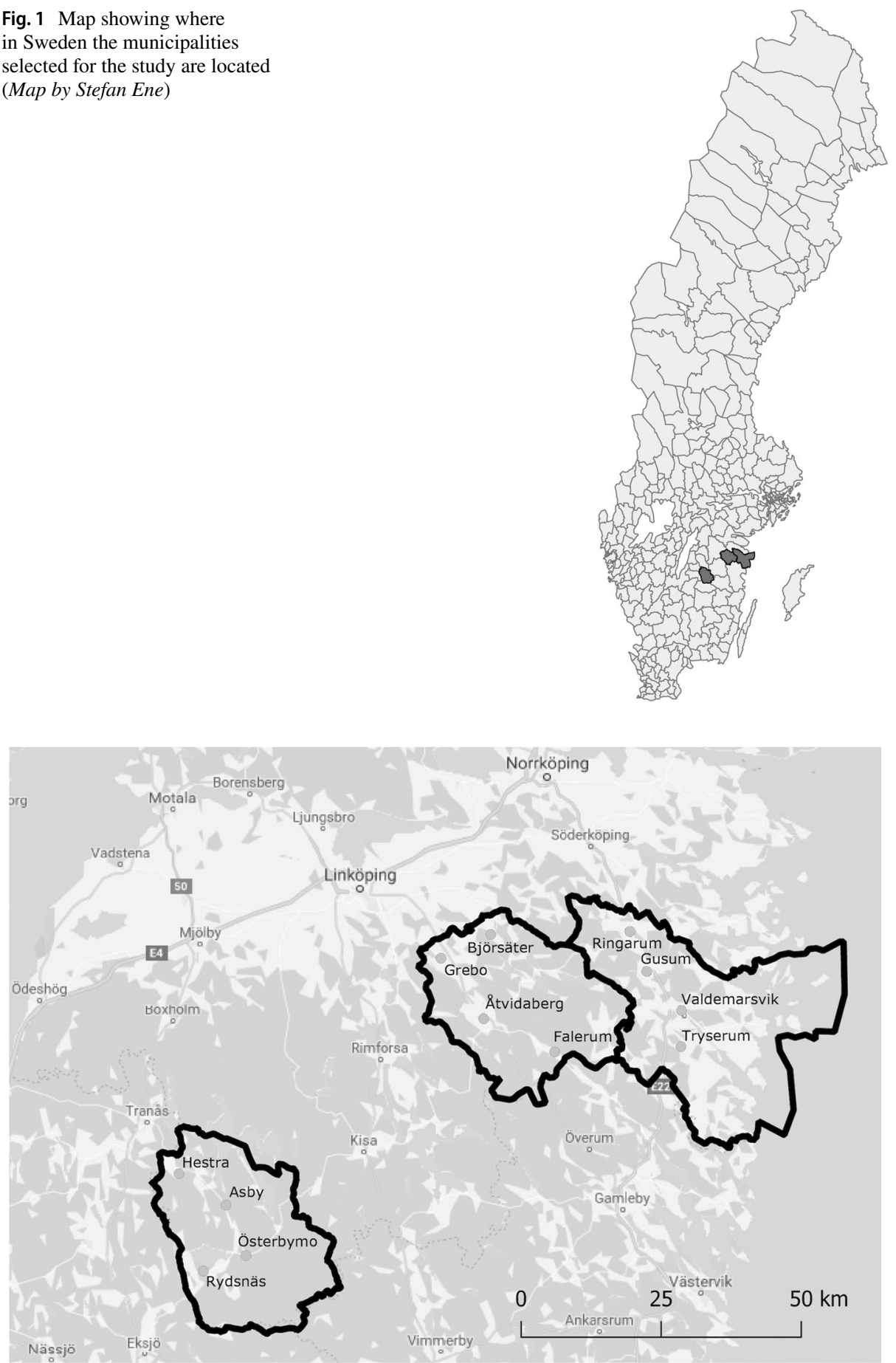

Fig. 2 Map showing the selected municipalities Ydre (municipal centre Österbymo), Åtvidaberg (municipal centre Åtvidaberg) and Valdemarsvik (municipal centre Valdemarsvik) and distances to neighbouring major centres, Eksjö, Linköping and Norrköping (Map by Stefan Ene) 
Table 1 Response rate based on age and municipality (per cent)

\begin{tabular}{lllll}
\hline Age group & Valdemarsvik & Ydre & Åvidaberg & Total \\
\hline $80-84$ & 58 & 61 & 65 & 62 \\
$85-89$ & 51 & 63 & 57 & 56 \\
$90-$ & 52 & 52 & 51 & 53 \\
Total & 55 & 61 & 61 & 59 \\
\hline
\end{tabular}

rural areas were asked. In the survey some questions were open-ended and the respondents had the possibility to comment, using their own words, on some of the questions, and this possibility was frequently used.

The questions asked in relation to their housing situation and plans concerned for example the time they had lived in the municipality and in their current dwelling, if they had recently moved or planned to move and if so where and why, where in the municipality they lived and household composition.

The first analyses were made within the Survey \& Report programme also used to design the survey. Further processing was conducted in Excel. Basic descriptive analyses were made at first where municipality, age and sex were used as background variables. In addition, cross tabulations were made. The study is cross-sectional as data was collected on one occasion only.

\subsection{Participants}

The postal survey and one reminder were sent out to all individuals aged 80 years and older, born between 1914 and 1934, in the three municipalities. The oldest respondent was 99 years old. The total population comprised 1562 individuals; 130 of them lived in assisted living facilities and as our interest was in people living in ordinary housing they were not included, nor were the 46 for which no address was available. As a result, the survey was sent to the remaining 1386 individuals. The response rate was close to $60 \%$ as 817 returned a completed survey. Out of the recipients of the survey, 23 individuals communicated that they were not willing or able to participate. Of the respondents, 453 were aged 80-84, 254 were aged 85-89 and 110 were 90 years old or older. This generally reflects the difference in size between the age groups but the rate of non-respondents was somewhat higher in the two older age groups (Table 1).

Older people have generally been left out of this type of surveys, which usually do not include those aged above 65. This is about to change and now older people are included in the annual Swedish Life Condition survey (ULF/SILC). The argument for excluding older people was that the response rate would be too small as lower response rates among older people have been shown in other studies (Kaldenberg et al. 1994). However, this is contradicted in our study, indicating that our empirical data contains information on a large group of older people that express their opinions about issues related to them ageing in a particular geographical context.

We can compare our respondents with those who did not respond according to four variables: municipality, age, sex and geographical location (rural/town). As shown in Table 1 the response rate in Valdemarsvik is somewhat lower than that in the other municipalities. The group of respondents is representative in relation to the whole population as regards rural living but a little skewed in regard to age, as there is a decrease in response with age 
Table 2 Division of age and sex among respondents, $\mathrm{n}=817$

\begin{tabular}{llll}
\hline & Men & Women & Total \\
\hline Age group & $\%$ & $\%$ & $\%$ \\
$80-84$ & 61 & 49 & 55 \\
$85-89$ & 28 & 35 & 31 \\
$90-$ & 11 & 16 & 13 \\
Total & 100 & 100 & 100 \\
\hline
\end{tabular}

(Table 2). The age effect may have influenced the results and should be kept in mind. It can be assumed that fewer older people in need of major assistance due to declining health answered the survey. The housing conditions of this group may also differ from those of the respondents. Thus, from the results we may underestimate the need for accessible housing, help and problems experienced in everyday life. As regards sex, men were over-represented among the respondents in the youngest and oldest age groups but not in the middle one (Table 2).

\subsection{Ethical considerations}

An ethical approval was not necessary to conduct this investigation as no sensitive personal data was collected. The collected data is neither presented nor analysed in a way where individuals can be identified. An introductory text to the survey explained that participation was voluntary, that no reference to the individual would be made in the analysis or the presentation of the results. By completing the survey the respondents agreed to contribute to the study.

\subsection{Limitations}

The municipalities in focus are defined as semi-rural and located in southern Sweden where population density is higher than in northern Sweden. As such the studied municipalities have the benefits of being close to larger, neighbouring municipalities with varied labour markets and extensive service provision including university hospitals in two of them. Thus, the municipalities can be considered less vulnerable than more remote areas and the results of the study may not be transferable to such areas. Even though the response rate to the survey was sufficient, also among the oldest age groups, it can be assumed that the most vulnerable older people are among the non-respondents but we neither have information about the socio-economic situation of non-respondents nor their health status or preferences. A supplementary survey, with in person questionnaires, to specifically target such groups would overcome such gaps but was not feasible within the scope of this study.

\section{Results}

In order to better understand the housing situation and the housing plans of the respondents some additional information collected in the survey about employment, household structure and car use is presented here. 
Table 3 Marital status of men, women, and in total

\begin{tabular}{llll}
\hline Marital status & Men & Women & Total \\
\hline Married & $62 \%$ & $26 \%$ & $42 \%$ \\
Cohabitation & $7 \%$ & $4 \%$ & $5 \%$ \\
Single & $31 \%$ & $72 \%$ & $54 \%$ \\
$\begin{array}{l}\text { Number of individuals } \\
\text { responding }\end{array}$ & 344 & 435 & 779 \\
\hline
\end{tabular}

${ }^{\text {a }}$ Seven women are married but live on their own (single)

\begin{tabular}{llll}
\hline Marital status of singles & Men & Women & Total \\
\hline Single-divorced & $15 \%$ & $9 \%$ & $11 \%$ \\
Single-widow/widower & $73 \%$ & $88 \%$ & $84 \%$ \\
Single-unmarried & $12 \%$ & $4 \%$ & $6 \%$ \\
Number of individuals responding & 117 & 335 & 452 \\
\hline
\end{tabular}

Table 4 Marital status of single living individuals, men, women, and in total

All the informants had been retired for many years, the majority (96\%) for at least 15 years. However, some indicated that they still work part-time or even full-time (5\%). Less than half, $42 \%$, were married and there is a big difference between men and women, $62 \%$ of the men were married but only $26 \%$ of the women (Table 3 ). The majority of the respondents lived alone, $54 \%$, as at this age many individuals have lost a partner. Of those living alone, $84 \%$ were widows or a widower, $11 \%$ were divorced and $6 \%$ unmarried (Table 4). Losing a partner is an important reason for residential mobility (Abramsson et al. 2014).

Questions about car driving and car transportation were asked in the survey. Forty per cent of the respondents drove their car regularly. Some of them, 10\%, could travel with a partner, $8 \%$ with a neighbour, friend or relative. It is clear that with age the car becomes a less used means of transportation, either due to a voluntary decision or as a result of declining health. In the oldest age group, only $14 \%$ drove whereas in the youngest $54 \%$ did. In the survey, some individuals (about 35) commented on the reason they had stopped driving and for all of them the reason was declining health. In our study, $46 \%$ stated that they were dependent on their car to manage grocery shopping, indicating that without car transportation everyday living becomes more complicated. Thus, the ability to drive and/or to access car transportation can act as an indicator of vulnerability in the current housing situation and can have an important influence on future housing decisions and on a decision to relocate. This importance to remain mobile in order to be able to remain in a depopulating place with a subsequent loss of services is discussed also by do Como and Santos (2012).

\section{The current housing situation of the surveyed age groups}

Rootedness, measured as time lived in a specific place, was strong among the respondents. Just over $40 \%$ grew up in the municipality in which they now lived. The vast majority had lived for many years in the municipality, $90 \%$ had lived there for more than 20 years. Only five individuals had lived in their respective municipality less than 5 years. 
Table 5 Housing tenure in the three municipalities

\begin{tabular}{lll}
\hline Housing tenure & Number & $\%$ \\
\hline Rented apartment & 288 & 36 \\
Tenant cooperative & 77 & 10 \\
Owner-occupation (single-family housing) & 333 & 42 \\
Owner-occupation (row housing) & 17 & 2 \\
Assisted living facility & 38 & 5 \\
Other & 41 & 5 \\
Total & 794 & 100 \\
\hline
\end{tabular}

${ }^{\text {a }}$ The survey was not sent to individuals permanently living in assisted living facilities. The selection of this housing type as an answer may depend on the fact that relocation had recently taken place to such a facility or that the respondents meant senior housing where some of them lived

Table 6 Geographical location of the dwelling, by municipality, and in total

\begin{tabular}{lllll}
\hline Where is your dwelling located? & Valdemarsvik & Ydre & Åtvidaberg & Total \\
\hline $\begin{array}{l}\text { In one of the towns or villages in the } \\
\text { municipality }\end{array}$ & $69 \%$ & $57 \%$ & $82 \%$ & $73 \%$ \\
In a rural setting & $31 \%$ & $43 \%$ & $18 \%$ & $27 \%$ \\
Number of individuals responding & 282 & 126 & 390 & 798 \\
\hline
\end{tabular}

Note Seven respondents stated that they live in a neighbouring municipality. Twelve did not reply to the question

Single-family housing was the most common housing type, followed by rented apartments (Table 5). In Ydre, the smallest municipality, living in an apartment was less common (36\%) than in the other municipalities where $50 \%$ of the respondents did so. This reflects the housing markets in the different municipalities, where the total number of apartments was smaller than in larger towns or cities. Tenant cooperatives are also generally not common in small municipalities, as is the case for Ydre municipality.

As older people are over-represented in rural areas in general we expected that many older people in these semi-rural municipalities live in the rural parts of the municipality, but that was not the case in this study. In all three municipalities a majority (73\%) lived in the municipal centre or other villages, only a minority lived in the rural parts of the municipalities (Table 6). There was a difference between the municipalities where a larger proportion of the elderly lived in a rural setting in Ydre, $43 \%$, compared to $18 \%$ in Atvidaberg. Still, in all three municipalities a majority lived in villages or towns. There was a significant difference between the villages and small towns in particular, as they varied in size and the range and type of services provided. Some were villages with a complete lack of services apart from mail delivery and home care to those individuals that have had such services granted.

There was no particular difference in geographical location between the age groups as regards living in towns/villages or in a rural setting. If we would have included those living in assisted living facilities the proportion and number of older people living in villages and towns would have increased, as these were all located in the municipal centre or other towns in the municipality. The proportion of respondents that stated that they had home care was higher among those living in the towns and villages $(21 \%)$ 
Table 7 Number of years in current dwelling, by municipality and in total

\begin{tabular}{|c|c|c|c|c|c|c|c|c|c|c|}
\hline \multirow{2}{*}{$\begin{array}{l}\text { Years in cur- } \\
\text { rent dwelling } \\
<1\end{array}$} & \multicolumn{2}{|c|}{ Valdemarsvik } & \multicolumn{2}{|l|}{ Ydre } & \multicolumn{2}{|c|}{ Åtvidaberg } & \multicolumn{2}{|c|}{ Other } & \multicolumn{2}{|c|}{ Total } \\
\hline & 15 & $5 \%$ & 7 & $6 \%$ & 9 & $2 \%$ & 0 & - & 31 & $4 \%$ \\
\hline $1-2$ & 20 & $7 \%$ & 3 & $2 \%$ & 11 & $3 \%$ & 1 & $13 \%$ & 35 & $4 \%$ \\
\hline $3-4$ & 14 & $5 \%$ & 14 & $11 \%$ & 27 & $7 \%$ & 2 & $25 \%$ & 57 & $7 \%$ \\
\hline $5-9$ & 40 & $14 \%$ & 8 & $6 \%$ & 58 & $15 \%$ & 4 & $50 \%$ & 110 & $14 \%$ \\
\hline $10-14$ & 27 & $9 \%$ & 10 & $8 \%$ & 43 & $11 \%$ & 0 & - & 80 & $10 \%$ \\
\hline $15-19$ & 27 & $9 \%$ & 4 & $4 \%$ & 24 & $6 \%$ & 1 & $13 \%$ & 57 & $7 \%$ \\
\hline $20-29$ & 37 & $13 \%$ & 13 & $10 \%$ & 39 & $10 \%$ & 0 & - & 89 & $11 \%$ \\
\hline $30-39$ & 27 & $9 \%$ & 20 & $16 \%$ & 33 & $9 \%$ & 0 & - & 80 & $10 \%$ \\
\hline $40-49$ & 23 & $8 \%$ & 14 & $11 \%$ & 65 & $17 \%$ & 0 & - & 102 & $13 \%$ \\
\hline$>50$ & 56 & $20 \%$ & 31 & $25 \%$ & 79 & $20 \%$ & 0 & - & 166 & $21 \%$ \\
\hline Total & 286 & $100 \%$ & 125 & $100 \%$ & 388 & $100 \%$ & 8 & $100 \%$ & 807 & $100 \%$ \\
\hline
\end{tabular}

Note Eight respondents stated that they lived in another municipality. This may be due to them being registered at the address to which the survey was sent, but living somewhere else

compared to those living in rural settings (15\%). This may be an indication of older people moving to a more central location when the needs for care increase.

Among our respondents $43 \%$ received help and support of some kind in everyday life, among those 90 years or older, this increased to 58\%. Most frequently this involved help with cooking, purchases, other household chores, payment of bills and visits to health care. The providers of support are usually partners, children or home care staff. Cleaning and fixing services ${ }^{1}$ were used by $21 \%$ of the respondents. The proportion of people who received home care or thought they were in need of home care, increased with age and in all age groups more men than women were recipients. The proportion of recipients of home care in this study was lower than the national average. Most individuals who received home care were supported with practical issues, ready-to-serve food as well as personal care and some had security alarms directly connected to home care. This type of support makes ageing in place possible and makes moves into residential care unnecessary or helps to prolong the time an individual can remain in housing in the ordinary housing market.

\section{Residential mobility and housing plans}

As noted above; many had lived for a long time in the municipality. Additionally, many had lived for a long time in their current dwelling. Just over $20 \%$ had lived in the same dwelling for more than 50 years and 55\% for more than 20 years (Table 7). On the other hand, it was evident that relocation took place in old age from the statements of the $27 \%$ that had lived in their dwelling for less than 10 years. As all respondents were 80 years or older a move had taken place after the age of 70 . This indicates another life cycle move in old age.

\footnotetext{
1 Fixing services are often provided for free but for a fixed amount of time, to older people by the municipalities in Sweden. When using this service older people can get help with issues such as putting up or taking down curtains or Christmas decorations, replacing light bulbs etc.
} 
Table 8 The type of housing those who considered moving would prefer to move to, by age and in total

\begin{tabular}{lllll}
\hline Age & $80-84$ & $85-89$ & $90-$ & Total \\
\hline Housing type & & & & \\
Rented apartment & $29 \%$ & $12 \%$ & $6 \%$ & $20 \%$ \\
Tenant cooperative & $5 \%$ & 0 & 0 & $3 \%$ \\
Single-family house (owner occupied) & $3 \%$ & 0 & 0 & $2 \%$ \\
Senior housing (apartments) & $18 \%$ & $13 \%$ & $9 \%$ & $15 \%$ \\
Extra care housing (apartments) & $30 \%$ & $24 \%$ & $43 \%$ & $30 \%$ \\
Assisted living facility & $23 \%$ & $48 \%$ & $49 \%$ & $34 \%$ \\
Other & $6 \%$ & $6 \%$ & $6 \%$ & $6 \%$ \\
Number of individuals responding & 160 & 86 & 39 & 286 \\
\hline
\end{tabular}

Note Only those considering a move replied to this question, $\mathrm{n}=286$

Among the oldest old, those aged 90 or more, $15 \%$ had lived in the current dwelling less than 2 years.

Only $12 \%$ stated that they had considered a move at some point in time and $22 \%$ stated that they did not know; $14 \%$ of the latter were in the oldest age group and the proportion of those who did not know was higher in the smallest municipality, 30\% as opposed to $23 \%$ in Valdemarsvik and 19\% in Atvidaberg, the largest of the three municipalities. Only very few, 12 individuals (2\%), considered a move to another municipality, but no one that lived in Ydre, the smallest of the three municipalities, did so. That is, $67 \%$ planned to remain where they were, about the same proportions in all three municipalities.

Even though it was clear that a majority would not move, ageing in place as an ideal as well as a real choice was strong, in the comments made in the survey a willingness to change the housing situation to better match changing needs could be seen. Most often then, what was demanded was some type of housing that was more easily maintained and possibly with some kind of support. In the youngest age group (80-84) some considered moving from their house to a rented apartment. There was an interest among all age groups in moving to a rented apartment (Table 8). Very few considered moving to single-family housing within these age groups. In all three age groups there was an evident interest in senior housing, extra care housing (that is not needs-assessed) and assisted living facilities (that are needs-assessed). The willingness to move to assisted living facilities increased with age and can be assumed to be a result of deteriorating health and an increased need for assistance.

Even though the willingness to age in place is strong, as has been seen in this as well as other studies, there is a turning point when, due to changing conditions, in particular health-related, older people are inclined to change their housing situation (Hagberg 2012). With a declining number of places in assisted living facilities there is a concern among older people that they will not be able to obtain a place when needed, in particular as this problem has featured on the national news (SOU 2007:103; 2008:113). In our study, 57\% trusted they would be offered a place when needed, $10 \%$ thought it might be difficult to be admitted, and 35\% thought they would not need a place at all (Table 9). There was a difference between the municipalities where the trust in the ability to be taken care of in an assisted living facility was greater in the smallest municipality, Ydre. Here, $72 \%$ assumed they would have no problems being offered a place. This is line with results from a previous study conducted in the same municipality where the trust in the social services to cater for its ageing population was high (Hagberg 2011). In the related field for open comments, 
Table 9 Subjective evaluation of future needs for a place in an assisted living facility, by age and in total

\begin{tabular}{|c|c|c|c|c|}
\hline Age & $80-84$ & $85-89$ & $90-$ & Total \\
\hline I trust I will be admitted to a place in an assisted living facility if I need one & $59 \%$ & $56 \%$ & $56 \%$ & $57 \%$ \\
\hline $\begin{array}{l}\text { I assume it will be difficult to be admitted to a place in an assisted living } \\
\text { facility if I need one }\end{array}$ & $10 \%$ & $5 \%$ & $18 \%$ & $10 \%$ \\
\hline I assume I will not need a place in an assisted living facility & $34 \%$ & $40 \%$ & $34 \%$ & $36 \%$ \\
\hline Number of individuals responding & 408 & 230 & 88 & 726 \\
\hline
\end{tabular}

several respondents commented on the available assisted living facilities and all did so favourably, such as "Assisted living in this municipality is very good"2 (man in Ydre); "I wish that all older people could live in a good assisted living facility with available care. I love the assisted living facility [name of facility]" (woman in Valdemarsvik). However, an expression of slight uncertainty was apparent in the following comment: "The assisted living facility in Ydre seems to be good but it is only when the need arises that you will know how it really works" (man, 85, in Ydre). Another issue is that assisted living is only offered in very few places in the municipality (Ydre and Åtvidaberg), which means that individuals that live far from these particular places will have to move from a familiar area, something they mentioned in the comments that they did not wish to do. Quite a few of the respondents, in total $36 \%$, assumed they would not need a place in an assisted living facility.

\section{Discussion}

The demographic shift in the coming years will show an increase in the number of people reaching the ages when declining health begins to take its toll and the need for care increases. This will particularly be evident in rural municipalities where the elderly will constitute a larger proportion of the population and require the municipalities to arrange for their well-being despite limited resources, a characteristic of municipalities suffering from depopulation. To provide adequate housing is one of the measures needed (Riksrevisionen 2014). The first thing the study showed was that older people were just as inclined as anyone else to respond to surveys related to their everyday life. This was an interesting finding in itself as older people previously have often been exempt from such studies. However, the response rate was somewhat lower among the very old $(90+)$. More women than men completed the survey but men were still over-represented since there were more women than men in the total population and as a result a higher participation of women would have been needed in order to achieve equal representation.

Household composition differed between men and women, where women to a much larger extent lived on their own as singles whereas men were married or cohabited. The large majority of the singles were widows or widowers. In combination with age, losing a partner is one of the main reasons to relocate in old age. To cater for single households and the housing needs of old women in particular is one of the challenges for the selected municipalities as many in this group have a low income (Sjögren Lindquist and Wadensjö 2012; Socialdepartementet 2011; Bonnet et al. 2010), and it was clear from the study that

${ }^{2}$ All comments written in the surveys by the respondents have been translated by the authors. 
women live alone to a larger extent than men. This has to be taken into account when considering housing needs for this group.

Most had access to some kind of transport, their own car, or the possibility to travel with a partner, relatives, friends or the municipal special transportation service, indicating a degree of independence that relates to the housing situation. Having access to car transportation facilitates living in the more rural areas of the municipality and in a house of your own that you have to maintain. Fourteen per cent lacked this option and did not have access to a car. However, almost all responded that grocery shopping worked well or quite well; thus, it can be assumed that the majority of the $14 \%$ live within a reasonable distance to the most important services or acquired sufficient help.

Many had lived for a very long time in their current dwelling. As such we can confirm earlier findings of residential immobility of older people defined as time in a current dwelling. The more rural the municipality, the stronger the rootedness and the more likely older people were to live in single-family housing. This immobility that was seen may be a result of the local housing market structure and of the fact that in order to change tenure, a change of geographical location has to take place, perhaps to the municipal centre or another village or town away from the current dwelling. Such remarks are found in the comments made by some of the respondents but would need to be investigated further. The fact that $27 \%$ had made a move during the last 10 years, that is, after the age of 70 , indicates a rather high relocation rate among this age group and can refer back to Clapham's discussion on older people's changing attitudes to housing (Clapham 2005). The comments made in the survey in addition confirmed that a strong place attachment (Rubinstein and Parmelee 1992) in a rural environment means that you know others in several generations, are known by others and also understand the social history of the place and values its geography; the place has become obvious.

Interestingly, the majority of the respondents lived in the municipal centre or other towns or villages, while $27 \%$ lived in a more rural setting. This suggests that the concern in this type of municipality for how to serve older people in rural areas with home and medical care might be unwarranted as the majority of the very old live in the municipal centre or other towns or villages, except perhaps in the smallest municipality chosen for this study, where still a large proportion of the respondents lived in what they considered a rural setting. To have a rather large proportion of the older population living in the more central parts of the municipalities can be considered an advantage for the municipalities when planning for old age care. The proportion of home care recipients is higher in the more central areas than in the more rural parts. This can be interpreted as reflecting a pragmatic shift—when the need for care increases, a move to more central areas is made.

For the most part, older people seem to trust that their housing situation will be solved if real needs arise due to failing health and they have to relocate to a needs-based assisted living facility. Still, $10 \%$ did have concerns about the situation. There could be an issue about the location of the assisted living facility, as concerns may be caused by the fear of having to relocate to another place in the municipality. Remarks that reveal anxiety to have to make such a relocation are found in the comments made by some of the respondents. Interestingly quite a few in the oldest age group did not think they would need to move into assisted living facilities at all in future.

This study contributes to a better understanding of the housing situation and the concerns about this situation of the very old in small municipalities in semi-rural areas, a group of people that has not been the target of many previous studies. It is clear from the study that moving in old age, as was done by $27 \%$ of our respondents after the age of 70 , is not infrequent and marks the existence of a life cycle stage where residential mobility is 
at play. As moves are performed at this time in life this result indicates a need for types of housing suitable to an ageing population. As women still outlive their partners and generally have a lower income in old age a discussion on affordable housing is needed. Moves in old age are often performed as a result of the loss of a partner and a companion. Such a loss may result in a need for housing that caters for social needs in old age in order to support the well-being of older people, that in addition, risk loosing other parts of their social networks such as old relatives and friends.

Further studies are needed to better understand the reasons for the choices made as well as the possibilities old people have to change their housing situation and the influence of local housing market conditions on the housing decisions of older people.

Acknowledgements This work was supported by a grant from the Centre for Municipality Studies, Linköping University.

Open Access This article is distributed under the terms of the Creative Commons Attribution 4.0 International License (http://creativecommons.org/licenses/by/4.0/), which permits unrestricted use, distribution, and reproduction in any medium, provided you give appropriate credit to the original author(s) and the source, provide a link to the Creative Commons license, and indicate if changes were made.

\section{References}

Abramsson, M., \& Andersson, E. (2015). Changing preferences with ageing: housing choices and housing plans of older people. Housing Theory and Society, 33(2), 1-25.

Abramsson, M., Elmqvist, A. \& Magnusson Turner, L. (2014). Äldres flyttningar och motiv till att flytta eller bo kvar [Residential mobility among older people and motives for moving or staying]. Skrifter från NISAL nr 10. Linköping universitety: NISAL/Hjälpmedelsinstitutet.

Abramsson, M., \& Niedomysl, T. (2008). Äldre personers flyttningar och boendepreferenser [Residential mobility and housing preferences among older people]. Fritzes, Stockholm: Institutet för framtidsstudier.

Andersson, E. (2008). Risk and security in home owning and renting: An interview study in Sweden. Research report 2008:1. Institute for housing and urban research, Uppsala University.

Andersson, E., \& Abramsson, M. (2012). Changing residential mobility rates of older people in Sweden. Ageing and Society, 32(6), 963-982.

Andersson, E., Naumanen, P., Ruonavaara, H., \& Turner, B. (2007). Housing, socio-economic security and risks. A qualitative comparison of household attitudes in Finland and Sweden. International Journal of Housing Policy, 7(2), 151-172.

Angelini, V., \& Laferrère, A. (2012). Residential mobility of the European Elderly. CESifo Economic Studies, 58(3), 544-569.

Bonnet, C., Gobillon, L., \& Laferrère, A. (2010). The effect of widowhood on housing and location choices. Journal of Housing Economics, 19, 106-120.

Boverket. (2013). Bostadsmarknaden 2013-2014 Med slutsatser från bostadsmarknadsenkäten 2013 [The housing market 2013-2014. With conclusions from the housing market survey]. Karlskrona: Boverket.

Burholt, V., \& Dobbs, C. (2012). Research on rural ageing: Where have we got to and where are we going in Europe? Journal of Rural Studies, 28(4), 432-446.

Chapman, S. A., \& Peace, S. M. (2008). Rurality and ageing well: 'a long time here'. In N. Keating (Ed.), Rural ageing. A good place to grow old? (pp. 21-32). Bristol: The Policy Press.

Clapham, D. (2005). The meaning of housing. A pathways approach. Bristol: Policy Press.

Colsher, P. L., \& Wallace, R. B. (1990). Health and social antecedents of relocation in rural elderly persons. Journal of Gerontology, 45(1), S32-S38.

de Jong, P. A., \& Brouwer, A. E. (2012). Residential mobility of older adults in the Dutch housing market: Do individual characteristics and housing attributes have an effect on mobility? European Spatial Research and Policy, 19(1), 33-47.

do Como, R. M., \& Santos, S. (2012). Between marginalisation and urbanisation: Mobilities and social change in southern Portugal. In C. Hedberg \& R. M. do Como (Eds.), Translocal ruralism: Mobility 
and connectivity in European Rural Spaces. The Geojournal library (Vol. 103, pp. 13-33). London: Springer.

Ekerdt, J., Sergeant, J. F., Dingel, M., \& Bowen, M. E. (2004). Household disbandment in later life. Journal of Gerontology: Social sciences, 59B(5), S265-S273.

Elsinga, M., \& Hoekstra, J. (2005). Homeownership and housing satisfaction. Journal of Housing and the Built Environment, 20(4), 401-424.

Fernandez-Carro, C., \& Evandrou, M. (2014). Staying put: Factors associated with ageing in one's 'lifetime home'. Insights from the European context. Research on Ageing and Social Policy, 2(1), 28-56.

Hagberg, J. E. (Ed.). (2011). Åldrande på landsbygden. Att leva som äldre i Ydre [Ageing in rural areas. Living in old age in Ydre]. Linköping: Linköpings universitet.

Hagberg, J.-E. (2012). Gamla människors tillhörighet till sin bostad [Older people's sense of belonging in their dwelling]. In M. Abramsson \& C. Nord (Eds.), Äldres boende-forskningsperspektiv $i$ Norden [Older people's housing-research perspectives in the Nordic countries]. Lund: Studentlitteratur.

Hillcoat-Nallétamby, S., \& Ogg, J. (2014). Moving beyond 'ageing in place': older people's dislikes about their home and nighbourhood environments as a motive for wishing to move. Ageing and Society, 34(10), 1771-1796.

Kaldenberg, D. O., Koenig, H. F., \& Becker, B. W. (1994). Mail survey response rate patterns in a population of the elderly: Does response deteriorate with age? The Public Opinion Quarterly, 58(1), 68-76.

Keating, N. (Ed.). (2008). Rural ageing. A good place to grow old?. Bristol: The Policy Press.

Larsson Ranada, A., \& Hagberg, J.-E. (2014). All the things I have-handling one's material room in old age. Journal of Aging Studies, 31, 110-118. https://doi.org/10.1016/j.jaging.2014.09.004.

Litwak, E., \& Longino, C. F. J. (1987). Migration patterns among the elderly: A Developmental perspective. The Gerontologist, 27(3), 266-272.

OECD (2007) OECD Regions at a glance 2007: Home ownership. https://www.oecdilibrary.org/urban-rural -and-regional-development/oecd-regions-at-a-glance-2007/homeownership_reg_glance-2007-27-en. Retrieved 16 May 2019.

Östsam (2012). Östgötarnas åldrande 2010-2030 [Ageing of the population in the county of Östergötland]. Linköping.

Paulsson, J. (2008). Boende och närmiljö för äldre [Housing and local environment of older people] (Nr 4). Stockholm: ARKUS.

Peace, S. M., Kellaher, L., \& Holland, C. (2006). Environment and Identity in later life. Maidenhead: Open University Press.

Riksrevisionen. (2014). Bostäder för äldre i avfolkningsorter (Housing for the elderly in depopulated areas) http://www.riksrevisionen.se/PageFiles/18923/RiR_2014_2_\%C3\%84ldresboende_anpassad.pdf. Retrieved 16 May 2016:RiR 2014:2.

Rubinstein, R. L., \& Parmelee, P. (1992). Attachment to place and the representation of the life course by the elderly. In I. Altman \& S. M. Low (Eds.), Place attachment (pp. 139-163). New York: Plenum Press.

Sandstedt, E., \& Abramsson, M. (2012). Ny bostadspolitik för att möta en åldrande befolkning [A new housing policy to meet and ageing population]. In M. Abramsson \& C. Nord (Eds.), Äldres boendeforskningsperspektiv i Norden [Older people's housing-research perspectives in the Nordic countries] (pp. 19-33). Lund: Studentlitteratur.

SCB. (2015:80). Sveriges befolkning ökar-men inte i hela landet [The Swedish population is incrasing but not in the whole country]. http://www.scb.se/sv_/Hitta-statistik/Artiklar/Sveriges-befolkning-okarmen-inte-i-hela-landet/. Retrieved 20 April 2016.

SCB (2018). Sveriges framtida befolkning 2017-2070: Störst folkökning att vänta bland de äldsta [Sweden's future population 2017-2070: Largest population increase to be expected among the oldest]. Statistiknyhet 2018-04-26. Accessed 26 Nov 2018.

Schön, P., Lagergren, M., \& Kåreholt, I. (2016). Rapid decrease in length of stay in institutional care for older people in Sweden between 2006 and 2012: Results from a population-based study. Health and Social Care in the Community, 24(5), 631-638.

SFS (2000:1383) Lag om kommunernas bostadsförsörjningsansvar [Law on the liability of the municipalities of housing provision].

Sjögren Lindquist, G. \& Wadensjö, E. (2012). Inkomstfördelningen bland pensionärer [Income division among the retired]. Studier i finanspolitik 2012/5. Rapport till Finanspolitiska rådet. Institutet för social forskning, Stockholms universitet.

Socialdepartementet (2011). Efter 65-inte bara pension. En analys av de äldres ekonomiska situation [After 65-not only pension. An analysis of the economic situation of older people]. Ds 2011:42.

Socialstyrelsen. (2016). Statistik om särskilt boende [Statistics on assisted living facilities]. 2016-12-5. 
SOU (2000:87). Regionalpolitiska utredningen slutbetänkande [Regional policy inquiry. Final report]. Stockholm: Fritzes offentliga publikationer.

SOU (2007:103). Bo för att leva-seniorbostäder och trygghetsbostäder. Delbetänkande av Äldreboendedelegationen [Housing to live in-senior housing and extra care hosuing. Interim report by the inquiry on older peoples' housing]. Stockholm: Fritzes offentliga publikationer.

SOU (2008:113). Bo bra hela livet-Slutbetänkande av äldreboendedelegationen [Housing for Life: Final Report of the inquiry on older peoples' housing]. Stockholm: Fritzes offentliga publikationer.

SOU (2015:85). Bostäder att bo kvar i. Bygg för gemenskap i tillgänglighetssmarta boendemiljöer [Houses to remain in. Build for community in accessible housing environments]. Stockholm, Fritzes.

Tatsiramos, K. (2006). Residential mobility and housing adjustment of older households in Europe. IZA (Forschungsinstitu zur Zukunft der Arbeit - Institute for the Study of Labour): IZA.

Publisher's Note Springer Nature remains neutral with regard to jurisdictional claims in published maps and institutional affiliations. 